\author{
Piotr Banasik ${ }^{1}$ \\ ORCID: 0000-0002-3604-4019 \\ Władysław Góral ${ }^{2}$ \\ ORCID: 0000-0003-0586-7191
}

\title{
PRECISION OF THE NEBRA DISC IN ASTRONOMICAL AND GEOMETRIC ASPECT
}

\author{
${ }^{1}$ AGH University of Science and Technology, Kraków, Poland \\ pbanasik@agh.edu.pl \\ ${ }^{2}$ AGH University of Science and Technology, Kraków, Poland \\ wgik@agh.edu.pl
}

Keywords: Nebra Disc, Sun, Moon, archeoastronomy

\begin{abstract}
The astronomical knowledge on the disc has been coded on two planes: horizontal and meridian. The range of sunrise and sunset directions during the year has been described on the horizontal plane. In turn, on the meridian (vertical) plane, the range of changes in the horizontal height and declination of the Sun in the upper culmination during the year and the Moon in its 18.61-year cycle were described. The relationships between the latitude of the place of observation, the horizontal height of the celestial body and its declination were described by means of geometric constructions. The presented article is a continuation of two publications [1] and [2], which describe the decryption of the Nebra disc. These publications were based on the interpretation of the results of angular measurements, made using a protractor with a scale of 0.5 degrees, without the use of a computer. The presented publication is based on a digital disc image obtained by means of its digitization. The obtained data was used for further calculations based on analytical geometry and graphic programs. This allowed to obtain results in a linear measure with a precision of less than $1 \mathrm{~mm}$.
\end{abstract}

\section{PRECYZJA DYSKU Z NEBRY W ASPEKCIE ASTRONOMICZNYM I GEOMETRYCZNYM}

Słowa kluczowe: Dysk z Nebry, Słońce, Księżyc, archeoastronomia

\begin{abstract}
Abstrakt
Wiedza astronomiczna na dysku została zakodowana na dwóch płaszczyznach: horyzontalnej i południkowej. Na płaszczyźnie horyzontalnej (poziomej) opisano zakres kierunków wschodu i zachodu Słońca w ciągu roku. Z kolei na płaszczyźnie południkowej (pionowej) opisano zakres zmiany wysokości horyzontalnej i deklinacji Słońca w kulminacji górnej w ciągu roku oraz Księżyca w jego 18,61-rocznym cyklu. Za pomocą konstrukcji geometrycznych opisano związki między szerokością geograficzną miejsca obserwacji, wysokością horyzontalną ciała niebieskiego i jego deklinacją. Prezentowany artykuł jest kontynuacją dwóch publikacji: [1], [2], w których opisano deszyfrację dysku z Nebry. Publikacje te były oparte na interpretacji wyników pomiarów kątowych, wykonanych za pomocą kątomierza o podziałce 0,5 stopnia, bez użycia komputera. Prezentowana publikacja bazuje na cyfrowym obrazie dysku, uzyskanym za pomocą jego digitalizacji. Uzyskane dane wykorzystano do dalszych obliczeń opartych na geometrii analitycznej oraz programach graficznych.
\end{abstract}




\section{INTRODUCTION}

The term Disc of Nebra comes from the name of the town of Nebra in Saxony Anhalt. It was excavated by treasure hunters in 1999. The disc was located in a stone mound in the archaeological site of Mittelberg, near Nebra. The director of Prehistory Museum in Halle, Saxony-Anhalt, did not get hold of the disc until 2002 [3]. The Nebra Disc is recognized as the greatest archaeological discovery at the end of the 20th century. In 2013, the disc was included in the UNESCO World Heritage List. Since then the disc has been the subject of archaeological research ([4], [5], [6], [7]) to discover its secret. It is very likely that a great deal of astronomical knowledge was recorded on the surface of the Nebra disc in an angular measurement by means of geometrical figures and point objects. It shows the ob- served movement of the Sun on the celestial sphere in the annual period and the Moon in the 18.6-year cycle. The presented article is based on two previous papers [1], [2], describing the method of Nebra disc decryption and its results. They were given in an angular measure, obtained with a protractor having an accuracy of about 0.5 degrees. The results presented in this publication are much more precise as the measurements were made on a digitized disc raster (Fig. 1 and 2). The calculation results were expressed in a linear measure with a precision of less than $1 \mathrm{~mm}$. It helped to estimate the average accuracy of the location of points identifying objects on the disc and the designated angles. In order to determine the location of objects on the disc, its image was used in the form of a raster in JPG format [8]. Digitalization included objects in the form of circles, bows, a sickle and holes around the perimeter of the disc. Most of these

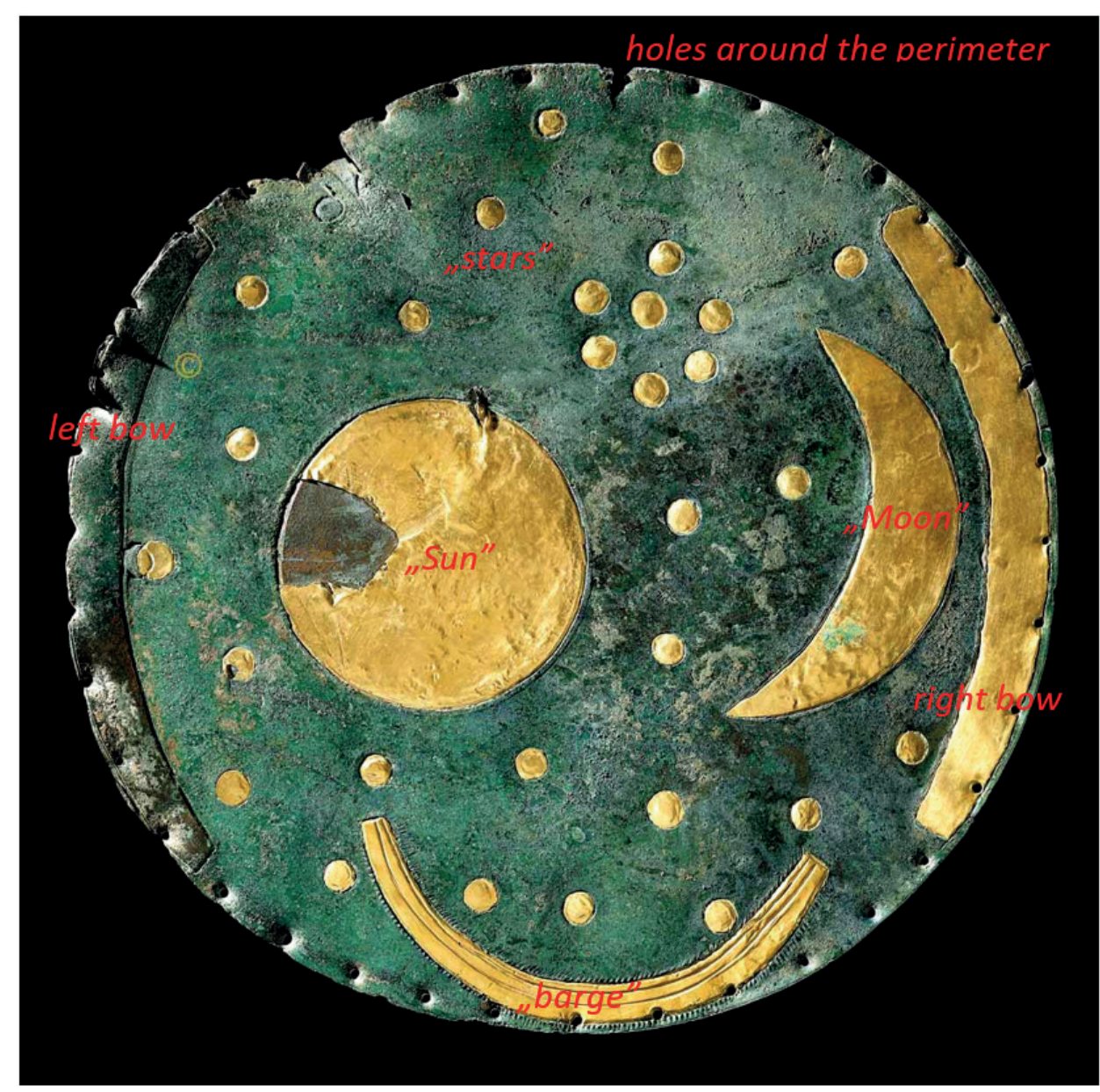

Fig. 1. Objects on the Nebra disc (based on [8])

Rys. 1. Obiekty na dysku z Nebry (na podstawie [8]) 
objects played an important role in the disc description, as presented in publications [1], [2]. Initially, for all the distinguished points, their coordinates in a rectangular and polar horizontal system were defined (Tab. 2). With their help, the angles between the directions marked by the points of the objects on the disc were calculated. The observed range of sunrise and sunset and the Moon are described on the horizon plane [4] and [1]. More complicated is the description of the range of the Sun in the annual period and the Moon in the 18.6-year cycle. It refers to the astronomical equatorial system in the meridional section [1], [12].

\section{DESCRIPTION OF THE NEBRA DISC RASTER AND ITS DIGITIZATION}

The $32 \mathrm{~cm}$ disc is made of bronze. On its surface, with the use of thin gold plates, a number of astronomical signs are depicted: a large circle symbolizing the "Sun", a figure symbolizing the "Moon" crescent, two bows on the left and right sides, a bow at the bottom of the disc symbolizing a solar barge, 33 small circles symbolizing "stars" and 39 holes around the perimeter of the disc (Fig. 1). Due to the visible traces of disc modification, and above all its damage, the location of some objects is difficult to identify. This mainly applies to a few holes around its circumference, as well as objects with only a trace (e.g. a bow on the left side, some small circles) (Fig. 2).
It was assumed that all of the above objects will be represented by the corresponding points. For circular objects, the identifying points are the centers of the circles (Fig. 3). For objects in the shape of bows, as well as "Moon" and "shoulders", points at their ends were assumed (Fig. 3). These points were assigned the designations given in Tab. 1.

Table 1. Numbering and marking of points identifying objects on the disc

Tabela 1. Numeracja i oznaczenia punktów identyfikujących obiekty na dysku

\begin{tabular}{|c|c|}
\hline Point Number & The name of the object \\
\hline $1-33$ & "stars" \\
\hline $\mathrm{S}_{0}$ & "Sun" \\
\hline $\mathrm{M}_{1}, \mathrm{M}_{2}$ & "Moon" \\
\hline $\mathrm{S}_{1}-\mathrm{S}_{2}, \mathrm{~S}_{3}-\mathrm{S}_{4}$ & bows \\
\hline $\mathrm{B}_{1}-\mathrm{B}_{4}$ & "barge" \\
\hline $101-139$ & $\begin{array}{c}\text { holes around the perimeter } \\
\text { of the disc }\end{array}$ \\
\hline $\begin{array}{c}\text { from } 201-\ldots \\
\text { and } \mathrm{M}, \mathrm{M}_{3}\end{array}$ & bonus points \\
\hline
\end{tabular}

Additional points, physically non-existent on the disc, determined with the help of geometric figures, were given consecutive numbers starting from 201 .
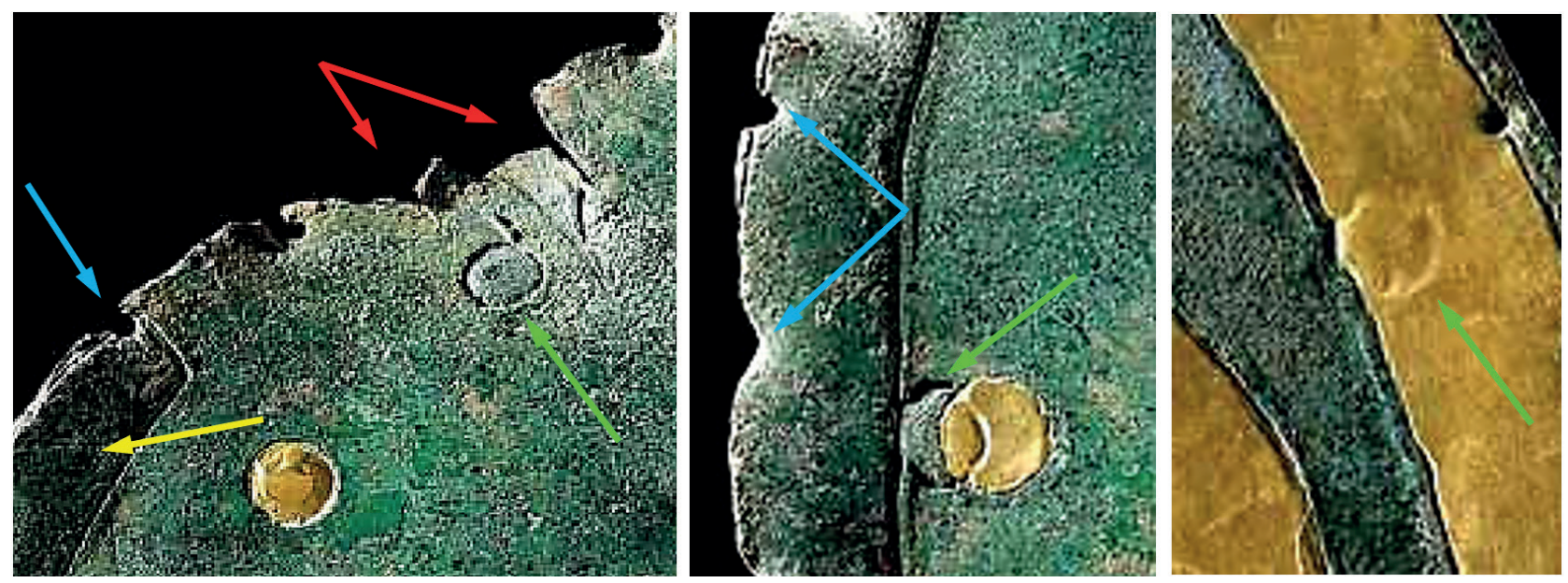

Fig. 2. Damaged fragments of the disc; red color - no holes on the damaged circumference of the disc; blue - holes with ambiguous location identification; green and yellow - traces of objects (based on [8])

Rys. 2. Uszkodzone fragmenty dysku; kolor czerwony - brak otworów na zniszczonym obwodzie dysku; niebieski - otwory o niejednoznacznej identyfikacji położenia; zielony i żółty - ślady po obiektach (na podstawie [8]) 
Additional points are also $\mathrm{M}, \mathrm{M}_{3}$. The location of all points on the disc is shown in Fig. 3. The digitization of the raster disc file from Nebra [8] was performed with CAD software [9]. Each point of a given object has been digitalized 5 times on the disc raster. The mean $\mathrm{X}$ and $\mathrm{Y}$ coordinates and their standard deviations were calculated. The exceptions are points 129-135, for which the identification is ambiguous. The coordinates of these points were determined once and should be treated as approximate. All coordinates and deviation values were converted to metric using the scale. Its value was obtained by comparing the disc diameter in the raster to the actual disc diameter $(32 \mathrm{~cm})$. The coordinates of all points on the disc in a rectangular and polar coordinates are given in Table 2 (except for points 101, 104 and 136 with an unidentified location).

For most of the points, the inaccuracy in determining their position, determined by means of the standard deviation, did not exceed $0.4 \mathrm{~mm}$. Larger deviation val- ues of approximately $0.7 \mathrm{~mm}$ were for points-holes on the perimeter of the disc. The smallest deviation values were obtained for the holes on the right side of the disc. The best identifiable holes were the following numbers: $102,103,106,108,110-125,127,138$ and 139. The average value of the standard deviation for all points on the disc was approximately $0.2 \mathrm{~mm}$. It determines the inaccuracy of digitalizing the raster image of a disc.

\section{THE HORIZONTAL SYSTEM OF COORDINATES OF THE NEBRA DISC}

In a horizontal system, the plane of the disc defines the plane of the horizon. A rectangular X, Y system is defined in this plane. It was defined by the axis being a bisector of the angle between the directions $\mathrm{S}_{1}-\mathrm{S}_{3}$ and $\mathrm{S}_{2}-\mathrm{S}_{4}$ taken from the ends of the right and left bows on the disc (Fig. 4). The angle $\left(\mathrm{S}_{1} 201 \mathrm{~S}_{2}\right)$ and the corre-

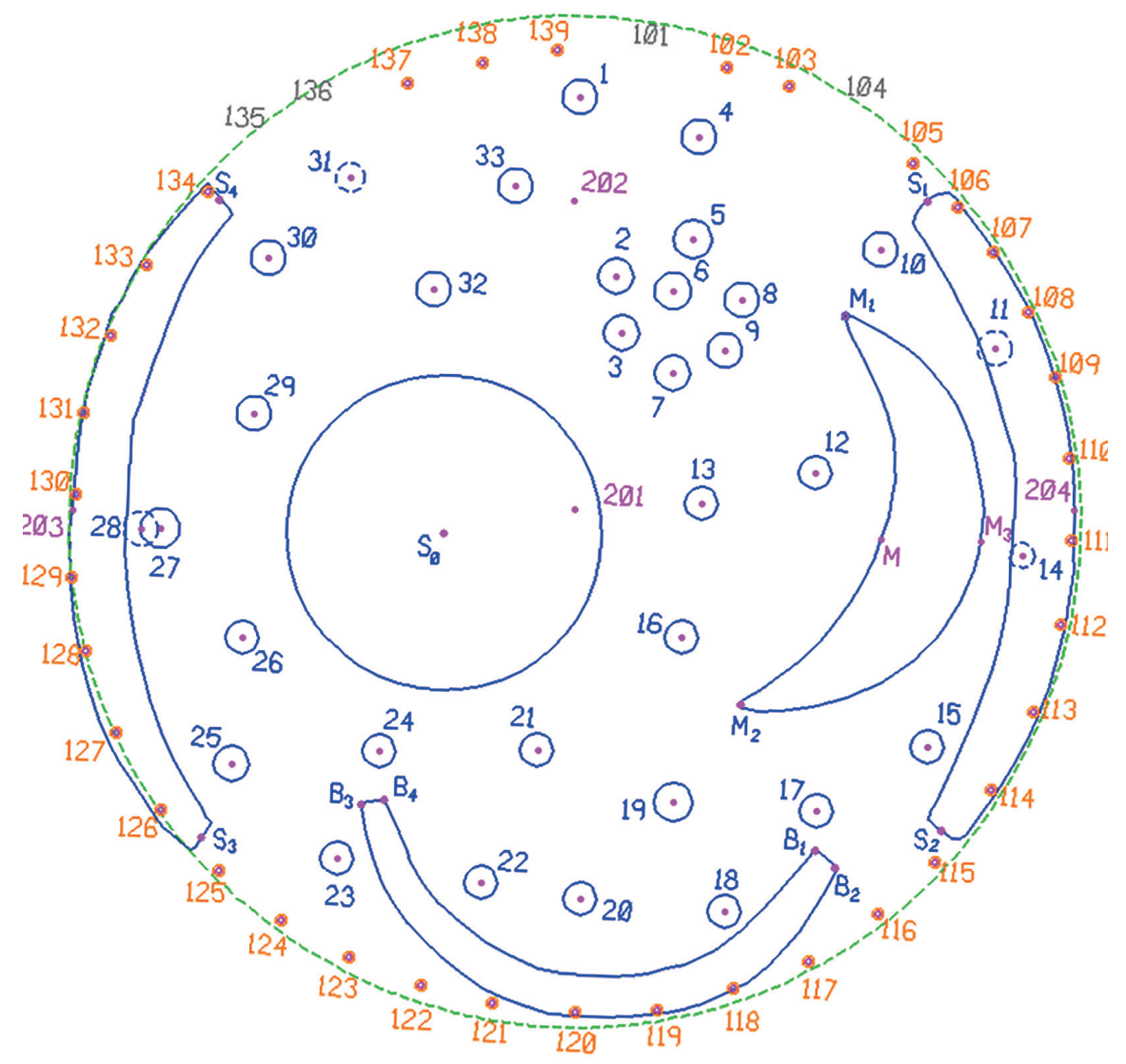

Fig. 3. Location of the points identifying objects on the disc and additional points

Rys. 3. Położenie punktów identyfikujących obiekty na dysku oraz punktów dodatkowych 
sponding angle $\left(\mathrm{S}_{3} 201 \mathrm{~S}_{4}\right)$ have the value $82.45^{\circ}$. This angle has been interpreted as the range of sunrise and sunset azimuths observed on the horizon during the year, at latitudes around $52^{\circ}$ [4] and [1]. Therefore, the angle $\left(\mathrm{S}_{4} 201 \mathrm{~S}_{1}\right)$ has the value $97.55^{\circ}$. The bisector of this angle forms an angle of $48.77^{\circ}$ with the direction $\left(201-S_{1}\right)$ or $\left(201-S_{2}\right)$ (Fig. 4). It is worth noting that the $\mathrm{Y}$ axis determined in this way is almost parallel to the line determined by points 1 and 20 . The distance of these points from the $\mathrm{Y}$ axis is $2.6 \mathrm{~mm}$ and $1.9 \mathrm{~mm}$, respectively. Thus, it can be considered that points 1 and 20 lie approximately on the bisector of the left and right disc bows. For the point 201, the coordinates $X_{201}=100 \mathrm{~cm}$ and $\mathrm{Y}_{201}=100 \mathrm{~cm}$ were assumed. In the $\mathrm{X}, \mathrm{Y}$ system, the rectangular coordinates of all points on the disc are expressed, as well as their polar coordinates: azimuth A relative to the north direction $(\mathrm{N})$, calculated clockwise and the distance d relative to point 201 (Tab. 2).

Table 2. Rectangular and polar coordinates, in a horizontal arrangement on the disc

Tabela 2. Współrzędne prostokątne i biegunowe, w układzie horyzontalnym na dysku

\begin{tabular}{|c|c|c|c|c|c|c|c|c|c|}
\hline NP & $X[\mathbf{c m}]$ & $Y[\mathbf{c m}]$ & $A\left[^{\circ}\right]$ & $d[\mathrm{~cm}]$ & NP & $X[\mathrm{~cm}]$ & $Y[\mathrm{~cm}]$ & $A\left[^{\circ}\right]$ & $d[\mathrm{~cm}]$ \\
\hline 1 & 100.18 & 113.06 & 0.81 & 13.1 & $\mathrm{~B}_{2}$ & 108.26 & 88.66 & 143.93 & 14.0 \\
\hline 2 & 101.31 & 107.40 & 10.02 & 7.5 & $\mathrm{~B}_{3}$ & 93.24 & 90.70 & 215.99 & 11.5 \\
\hline 3 & 101.49 & 105.61 & 14.88 & 5.8 & $\mathrm{~B}_{4}$ & 94.00 & 90.84 & 213.23 & 11.0 \\
\hline 4 & 103.95 & 111.80 & 18.52 & 12.4 & 102 & 104.84 & 114.01 & 19.07 & 14.8 \\
\hline 5 & 103.76 & 108.57 & 23.68 & 9.4 & 103 & 106.81 & 113.40 & 26.94 & 15.0 \\
\hline 6 & 103.12 & 106.94 & 24.18 & 7.6 & 105 & 110.73 & 110.95 & 44.43 & 15.3 \\
\hline 7 & 103.12 & 104.34 & 35.68 & 5.3 & 106 & 112.11 & 109.57 & 51.68 & 15.4 \\
\hline 8 & 105.29 & 106.64 & 38.55 & 8.5 & 107 & 113.25 & 108.16 & 58.39 & 15.6 \\
\hline 9 & 104.74 & 105.04 & 43.25 & 6.9 & 108 & 114.36 & 106.24 & 66.51 & 15.7 \\
\hline 10 & 109.70 & 108.22 & 49.70 & 12.7 & 109 & 115.23 & 104.20 & 74.57 & 15.8 \\
\hline 11 & 113.30 & 105.09 & 69.06 & 14.2 & 110 & 115.66 & 101.61 & 84.13 & 15.7 \\
\hline 12 & 107.62 & 101.19 & 81.11 & 7.7 & 111 & 115.71 & 99.04 & 93.48 & 15.7 \\
\hline 13 & 104.02 & 100.20 & 87.08 & 4.0 & 112 & 115.38 & 96.38 & 103.25 & 15.8 \\
\hline 14 & 114.17 & 98.57 & 95.75 & 14.2 & 113 & 114.52 & 93.61 & 113.75 & 15.9 \\
\hline 15 & 111.15 & 92.49 & 123.96 & 13.4 & 114 & 113.20 & 91.13 & 123.91 & 15.9 \\
\hline 16 & 103.37 & 95.96 & 140.15 & 5.3 & 115 & 111.41 & 88.84 & 134.37 & 16.0 \\
\hline 17 & 107.63 & 90.48 & 141.26 & 12.2 & 116 & 109.60 & 87.23 & 143.08 & 16.0 \\
\hline 18 & 104.76 & 87.29 & 159.48 & 13.6 & 117 & 107.42 & 85.72 & 152.53 & 16.1 \\
\hline 19 & 103.14 & 90.77 & 161.22 & 9.7 & 118 & 105.03 & 84.87 & 161.61 & 15.9 \\
\hline 20 & 100.20 & 87.70 & 179.05 & 12.3 & 119 & 102.63 & 84.18 & 170.56 & 16.0 \\
\hline 21 & 98.83 & 92.41 & 188.73 & 7.7 & 120 & 100.03 & 84.08 & 179.89 & 15.9 \\
\hline 22 & 97.04 & 88.22 & 194.10 & 12.1 & 121 & 97.39 & 84.40 & 189.51 & 15.8 \\
\hline 23 & 92.51 & 88.99 & 214.23 & 13.3 & 122 & 95.16 & 84.97 & 197.84 & 15.8 \\
\hline 24 & 93.81 & 92.38 & 219.06 & 9.8 & 123 & 92.88 & 85.83 & 206.67 & 15.9 \\
\hline 25 & 89.16 & 91.96 & 233.44 & 13.5 & 124 & 90.75 & 87.03 & 215.50 & 15.9 \\
\hline 26 & 89.50 & 95.99 & 249.08 & 11.2 & 125 & 88.75 & 88.58 & 224.59 & 16.0 \\
\hline 27 & 86.92 & 99.41 & 267.41 & 13.1 & 126 & 86.92 & 90.50 & 234.03 & 16.2 \\
\hline
\end{tabular}


Table 2 cont. / Tabela 2 cd.

\begin{tabular}{|c|c|c|c|c|c|c|c|c|c|}
\hline NP & $X[\mathbf{c m}]$ & $Y[\mathrm{~cm}]$ & $A\left[^{\circ}\right]$ & $d[\mathrm{~cm}]$ & NP & $X[\mathrm{~cm}]$ & $Y[\mathrm{~cm}]$ & $\boldsymbol{A}\left[{ }^{\circ}\right]$ & $d[\mathrm{~cm}]$ \\
\hline 28 & 86.29 & 99.42 & 267.58 & 13.7 & 127 & 85.52 & 92.96 & 244.06 & 16.1 \\
\hline 29 & 89.85 & 103.06 & 286.77 & 10.6 & 128 & 84.54 & 95.52 & 253.84 & 16.1 \\
\hline 30 & 90.33 & 107.96 & 309.47 & 12.5 & 129 & 84.12 & 97.87 & 262.37 & 16.0 \\
\hline 31 & 92.90 & 110.52 & 326.01 & 12.7 & 130 & 84.22 & 100.50 & 271.82 & 15.8 \\
\hline 32 & 95.57 & 106.99 & 327.63 & 8.3 & 131 & 84.49 & 103.06 & 281.15 & 15.8 \\
\hline 33 & 98.13 & 110.24 & 349.64 & 10.4 & 132 & 85.32 & 105.52 & 290.61 & 15.7 \\
\hline $\mathrm{S}_{0}$ & 95.86 & 99.27 & 260.04 & 4.2 & 133 & 86.48 & 107.75 & 299.82 & 15.6 \\
\hline $\mathrm{M}$ & 99.08 & 109.69 & 95.42 & 9.7 & 134 & 88.41 & 110.05 & 310.94 & 15.3 \\
\hline $\mathrm{M}_{1}$ & 108.55 & 106.14 & 54.33 & 10.5 & 137 & 94.72 & 113.51 & 338.67 & 14.5 \\
\hline $\mathrm{M}_{2}$ & 105.26 & 93.84 & 139.50 & 8.1 & 138 & 97.09 & 114.16 & 348.38 & 14.5 \\
\hline $\mathrm{M}_{3}$ & 99.04 & 112.86 & 94.29 & 12.9 & 139 & 99.48 & 114.53 & 357.95 & 14.5 \\
\hline $\mathrm{S}_{1}$ & 111.14 & 109.76 & 48.77 & 14.8 & 201 & 100.00 & 100.00 & - & - \\
\hline $\mathrm{S}_{2}$ & 111.60 & 89.84 & 131.23 & 15.4 & 202 & 100.00 & 109.80 & - & - \\
\hline $\mathrm{S}_{3}$ & 88.20 & 89.66 & 228.77 & 15.7 & 203 & 84.12 & 100.00 & - & - \\
\hline $\mathrm{S}_{4}$ & 88.78 & 109.83 & 311.23 & 14.9 & 204 & 115.81 & 100.00 & - & - \\
\hline $\mathrm{B}_{1}$ & 107.61 & 89.22 & 144.77 & 13.2 & & & & & \\
\hline
\end{tabular}

Using the azimuth values of the directions from point 201 to the hole-points on the perimeter of the disc (points in the range 101-139), the values of the angles based on these points and the point 201 as the angle vertex were calculated. It can be assumed that these holes could be a scale that would allow the angle to be measured (similar to using a protractor). The mean values of the angles between the points-holes are given in Table 3 .

Table 3. Measurements of angles based on points-holes on the circumference of the disc (points numbered 101-139) with the vertex in the center of the disc (point 201)

Tabela 3. Miary kątów opartych na punktach-otworach na obwodzie dysku (punkty o numerach101-139) z wierzchołkiem w centrum dysku (punkt 201)

\begin{tabular}{|c|c|c|}
\hline \multirow{2}{*}{ Points-holes } & \multicolumn{2}{|c|}{ Value of the angle [ ${ }^{\circ}$ ] } \\
\cline { 2 - 3 } & Average & $\min / \mathbf{m a x}$ \\
\hline all identified & $9.2 \pm 0.9$ & $6.7 / 11.1$ \\
\hline $\begin{array}{c}\text { selected with the best } \\
\text { identification }\end{array}$ & $9.4 \pm 0.6$ & $8.3 / 10.5$ \\
\hline
\end{tabular}

This table shows that the average value of the angle formed by the arms against the holes in the disc is about $9^{\circ}$.

\section{LINES ON THE DISC MARKED WITH POINTS}

Publications [1] and [10] describe many straight lines that pass through two or more points on the disc. In case of lines marked with two points, the position of the straight line is unambiguous. However, in the case of lines designated with 3 or more of them, the line is a linear approximation. An example are the two lines noticed in [10], forming the shape of the letter "L" (Fig. 3 in [10]). Each of them is designated by 4 points. The authors [10] suggested that these lines form an angle close to a right angle. The approximation of points with the help of a line can be described by the coefficient of linear determination $\mathrm{R}^{2}$, [11]. It determines the fit of points to the straight line. If the points are collinear, $\mathrm{R}^{2}=1$. The smaller the numerical value of $\mathrm{R}^{2}$, the less collinear the points are. Knowing the $\mathrm{X}$ and $\mathrm{Y}$ 


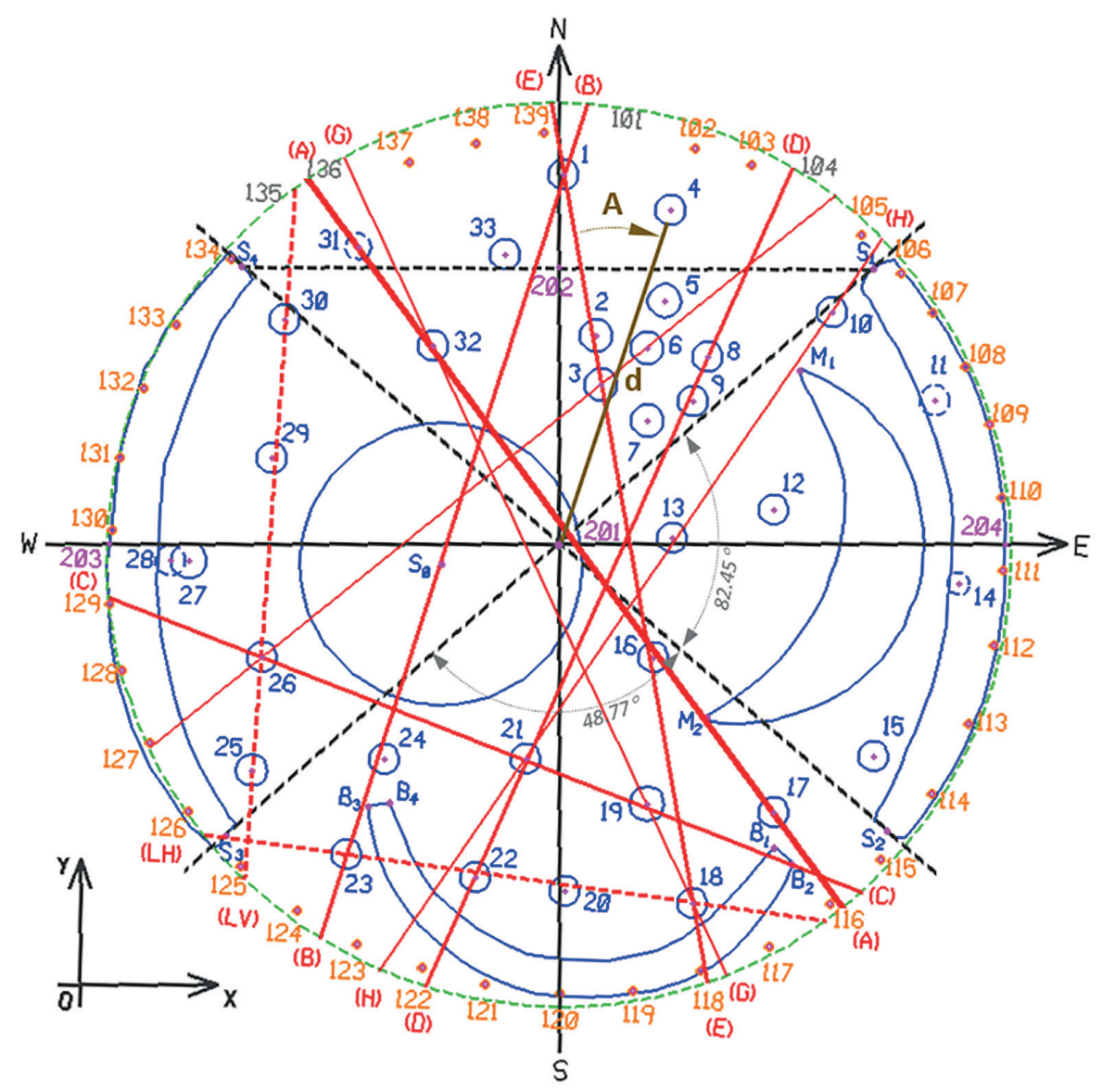

Fig. 4. Graphical presentation of straight lines based on: 3,4 and 5 points in a horizontal position Rys. 4. Graficzna prezentacja linii prostych na podstawie: 3, 4 i 5 punktów w układzie horyzontalnym

coordinates of the points, it is possible to calculate the value of the $\mathrm{R}^{2}$ coefficient for any group of points. For example, points 30,29,26,25, forming the vertical arm of the letter "L", (Fig. 3 in [10]) are approximated by a straight line with the coefficient $\mathrm{R}^{2}=0.9836$. On the other hand, the horizontal line marked by points 23,22 , 20,18 is approximated by a line with the coefficient $\mathrm{R}^{2}=0.9777$. The angle formed by both straight lines (the arms of the letter "L") is $94.2^{\circ}$. Table 4 shows the approximation results of several exemplary groups of "almost collinear" points with coefficients $\mathrm{R}^{2}$ close to 1.0 . The last column of Table 4 shows the deviations (d) of the points from the lines with the equation $(\mathrm{Y}=\mathrm{a} \mathrm{X}+\mathrm{b})$ approximating the points, as shown in Fig. 5.

All lines in Table 4 are shown in Figure 4. They are marked with letters from $\mathrm{A}$ to $\mathrm{H}$. The lines forming the letter "L" from publication [10] are marked with "LV" and "LH". In addition to the lines listed in
Table 4, you can create even more such lines with different fit to points. It is certain that the directions or angles important to the user of the disc were established by means of straight lines passing through specific points on the disc. Among such lines, the ones with the $\mathrm{R}^{2}$ coefficient close to 1 and with a small range (dmin - dmax) stand out.

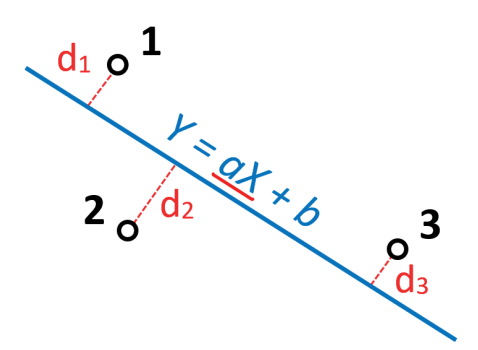

Fig. 5. Example of approximating points with a straight line Rys. 5. Przykład aproksymacji punktów linią prostą 
Table 4. Examples of approximation of points with straight lines

Tabela 4. Przykłady aproksymacji punktów liniami prostymi

\begin{tabular}{|c|c|c|c|c|c|c|c|}
\hline \multirow{2}{*}{$\begin{array}{l}\text { Designation } \\
\quad \text { lines }\end{array}$} & \multirow{2}{*}{$\begin{array}{l}\text { Number } \\
\text { of points }\end{array}$} & \multirow{2}{*}{ Point numbers } & \multirow{2}{*}{$\mathbf{R}^{2}$} & \multirow[t]{2}{*}{$\mathbf{A}\left[{ }^{\circ}\right]$} & \multicolumn{2}{|c|}{$Y=a X+b$} & \multirow{2}{*}{$\begin{array}{c}\mathrm{d}_{\min } ; \mathrm{d}_{\max } ; \mathbf{d}_{\mathrm{sr}} \\
{[\mathrm{cm}]}\end{array}$} \\
\hline & & & & & $a$ & $b$ & \\
\hline A & \multirow{2}{*}{5} & $31-32-16-\mathrm{M}_{2}-17$ & 0.9997 & 143.99 & -1.3680 & 237.63 & $0.01 ; 0.15 ; 0.07$ \\
\hline $\mathrm{B}$ & & $23-\mathrm{B}_{3}-24-\mathrm{S}_{0}-1$ & 0.9991 & 72.27 & 0.3137 & 64.73 & $0.01 ; 0.13 ; 0.06$ \\
\hline $\mathrm{C}$ & \multirow{3}{*}{4} & $26-21-19-B_{2}$ & 0.9997 & 111.26 & -0.3889 & 130.82 & $0.02 ; 0.06 ; 0.04$ \\
\hline $\mathrm{D}$ & & $22-21-9-8$ & 0.9996 & 24.44 & 2.1996 & -125.13 & $0.04 ; 0.09 ; 0.07$ \\
\hline $\mathrm{E}$ & & $1-2-3-18$ & 0.9991 & 170.01 & -5.6703 & 681.34 & $0.01 ; 0.09 ; 0.04$ \\
\hline $\mathrm{F}$ & \multirow{3}{*}{3} & $26-3-6$ & 1.0000 & 51.21 & 0.8039 & 24.04 & $0.00 ; 0.01 ; 0.01$ \\
\hline $\mathrm{G}$ & & $32-19-18$ & 1.0000 & 154.99 & -0.4664 & 145.47 & $0.00 ; 0.00 ; 0.00$ \\
\hline $\mathrm{H}$ & & 21-13-10 & 0.9997 & 55.51 & 1.4557 & -51.58 & $0.04 ; 0.09 ; 0.06$ \\
\hline LV [10] & 4 & $30-29-26-25$ & 0.9836 & 183.98 & 14.1217 & -1167.11 & $0.00 ; 0.09 ; 0.05$ \\
\hline LH [10] & 4 & $23-22-20-18$ & 0.9777 & 98.16 & -0.1401 & 101.87 & $0.08 ; 0.13 ; 0.09$ \\
\hline
\end{tabular}

\section{THE CELESTIAL EQUATORIAL SYSTEM ON THE NEBRA DISC}

Initially, a cardinal horizontal system was determined on the surface of the disc and the directions of sunrise and sunset over the year were documented. Much of the knowledge of astronomy on the Nebra disc is graphically recorded. The declination $\delta$ was determined with the help of the celestial equatorial system in the meridional section. In turn, in the celestial horizontal system in the meridional section, the horizontal height $h$ or the zenith distance $z=90^{\circ}-h$ of the celestial body was determined. These systems on the meridian plane are related to the geographical system by means of latitude $\varphi$ of the observation site [1], [12]. The coordinates: $\delta, \mathrm{h}, \varphi, \mathrm{h}$, appear in two equations describing the upper culmination of a celestial body.

$$
\begin{aligned}
& h_{S}=90^{\circ}-\varphi+\delta \\
& h_{N}=90^{\circ}+\varphi-\delta
\end{aligned}
$$

Equation (1) relates to the upper celestial body culminating south of the zenith and equation (2) north of the zenith. These are the basic equations encoded on the Nebra disc. When the celestial body is at the equator $\left(\delta=0^{\circ}\right)$, then equation (1) asks for the form $h_{s}=90^{\circ}-\varphi$, which determines the horizontal height of the celestial equator. In the case when the celestial body is at zenith $\left(\mathrm{h}=90^{\circ}\right)$, then equations (1) and (2) simplify to the form $\varphi=\delta$. Based on the measurement of the horizontal height of the celestial body at the time of its upper culmination, it is possible to determine the horizontal height of the celestial equator, and then the latitude of the observation site. An observer at a location with known latitude $\varphi$ can calculate the declination of the observed celestial body by measuring the horizontal height $\mathrm{h}$. In the meridional section, objects on the disc refer to symbols of celestial bodies.

This system provides the calculated values of declination and polar distances for all point features on the disc (Tab. 5). In particular, the extent of the change in the declination and horizontal height (or zenith distance) of the Sun in the upper culmination over the annual period and the Moon over the 18.6-year cycle has been described on the celestial meridian plane. The system parameters are described by the angle $\mathrm{M}_{1} \mathrm{~S}_{0} \mathrm{M}_{2}$ (Fig. 6).

The center of the circle, symbolising the Sun, marks the beginning of $\mathrm{S}_{0}$ of the celestial equatorial system. The lines connecting the point $S_{0}$ with the points $M_{1}$ and $\mathrm{M}_{2}$, defined by the extreme points of the sickle, the symbol of the Moon, define the angle $\mathrm{M}_{1} \mathrm{~S}_{0} \mathrm{M}_{2}$. The bisector $\mathrm{S}_{0} \mathrm{M}$ of this angle is marked by the celestial equator $\mathrm{E}_{\mathrm{N}}-\mathrm{E}_{\mathrm{S}}$ (Fig. 6). It is worth noting that the bisector $\mathrm{S}_{0} \mathrm{M}$ practically passes through points 27 and 28 . The distance of these points from the bisector is $0.14 \mathrm{~mm}$ and $0.10 \mathrm{~mm}$, respectively. Therefore, with high preci- 


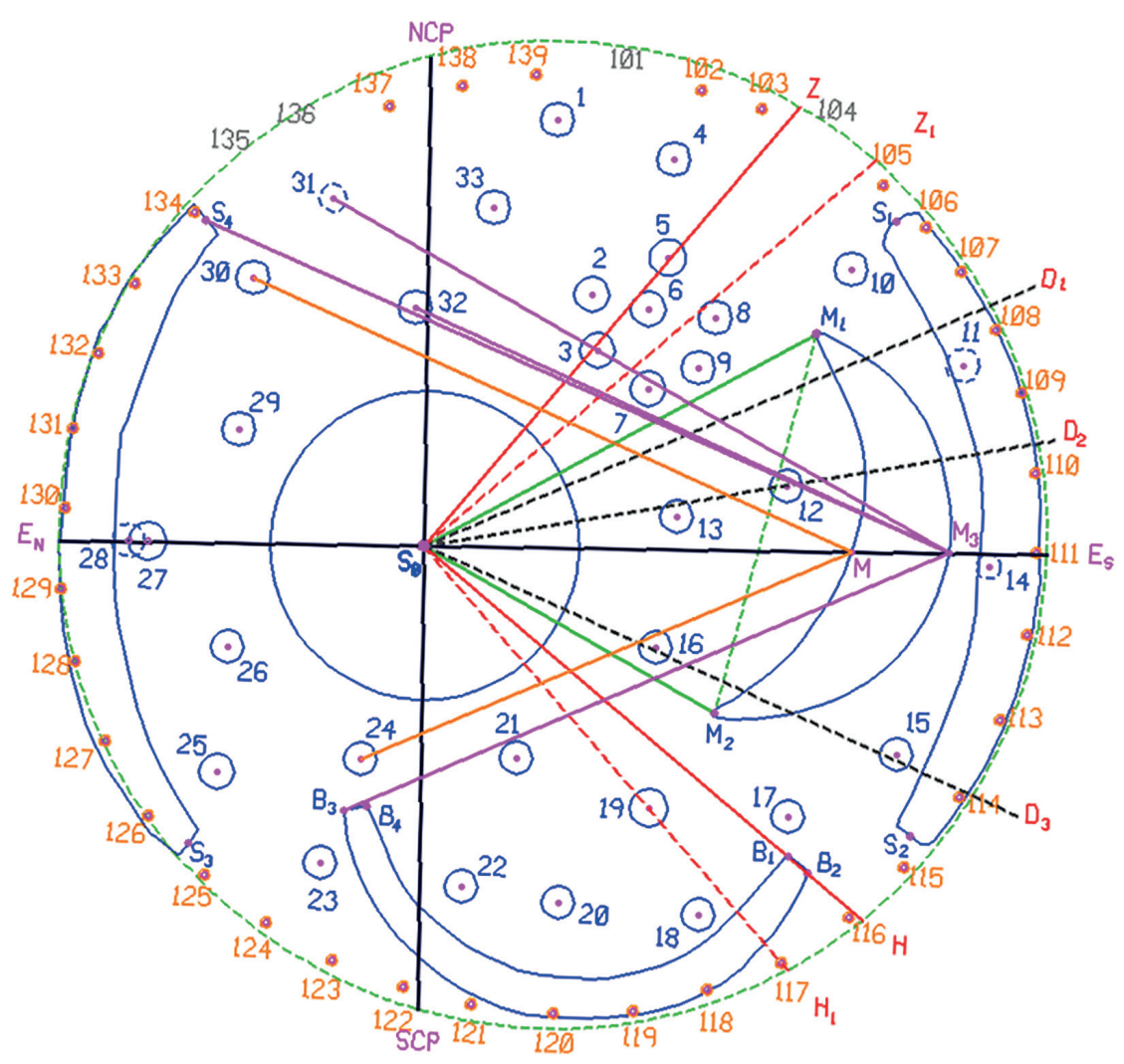

Fig. 6. Graphical description in the meridian cross-section of the upper culmination range of the Moon and the Sun in the celestial systems: equatorial and horizontal

Rys. 6. Graficzny opis w przekroju południkowym zakresu kulminacji górnej Księżyca i Słońca w układach niebieskich: równikowym i horyzontalnym

sion, it can be concluded that the bisector, i.e. the celestial equator, is determined by the physical points on the disc: 27, 28 and $\mathrm{S}_{0}$. A line perpendicular to the equator at $\mathrm{S}_{0}$ marks the world axis, defined by the North Celestial Pole (NCP) and the South Celestial Pole (SCP). The introduction of the celestial equatorial system significantly facilitates the description of the Nebra disc decryption. Measure of angle $\mathrm{M}_{1} \mathrm{~S}_{0} \mathrm{M}_{2}$ is $58.43^{\circ}$. It is the sum of two angles: $\mathrm{MS}_{0} \mathrm{M}_{1}\left(29.21^{\circ}\right)$ and $\mathrm{MS}_{0} \mathrm{M}_{2}\left(29.22^{\circ}\right)$ (Tab. 5). So the mean value of these angles with respect to the equator is $29.21^{\circ}$. The creators of the Nebra disc, using the angles $\mathrm{M}_{2} \mathrm{~S}_{0} \mathrm{M}_{1}$, graphically recorded the range of change in the declination $\delta_{\mathrm{M}}$ of the Moon in its 18.6-year cycle. During this period, the declination of the Moon varies in the range $-\varepsilon-i \leq \delta_{M} \leq \varepsilon+i$, where $\varepsilon$ is the inclination of the ecliptic to the equator. The value of the inclination is variable and over 3000 years ago it was $\varepsilon=23.85^{\circ}$. The i represents the average value of the inclination of the Moon's orbit to the ecliptic. This value is considered constant and amounts to $i=5.15^{\circ}$. The declination of the Sun varies in the range $-\varepsilon \leq \delta_{S} \leq \varepsilon$. over the year. This range is expressed by the angle $\mathrm{D}_{3} \mathrm{~S}_{0} \mathrm{D}_{1}$. Its value is $47.70^{\circ}$, which corresponds to the value of $2 \varepsilon$. Using the formula (1), the observer can determine the horizontal height of the Sun and the Moon at their upper culmination, in accordance with the above-mentioned ranges of declination change. It is worth noting that the line $\mathrm{S}_{0}-\mathrm{D}_{3}$ through points 15 and 16 at a distance of $2.1 \mathrm{~mm}$ and $1.2 \mathrm{~mm}$ respectively.

The Nebra disc allows us to graphically determine the horizontal height (zenith distance) of the celestial body for any chosen latitude $\varphi$. A characteristic horizontal line is the line $\mathrm{S}_{0}-\mathrm{B}_{2}$ pointing to the edge of the "sun barge" and marked in Figure 5 with the symbol (H). Its declination is $\delta=-39.76^{\circ}$ (Tab. 5). This line also passes through point $B_{1}$. The zenith line $S_{0}-Z$ (perpendicular to the horizontal line) passes near points 3 and 5. The distance of these points from the line is 
Table 5. Polar coordinates: $\mathrm{p}$ - angular polar distance, $\delta$ - declination and $\mathrm{s}-$ distance of a given point on the disc in relation to the point $\mathrm{S}_{0}$ in the celestial equatorial system

Tabela 5. Współrzędne biegunowe: $\mathrm{p}$ - kątowa odległość biegunowa, $\delta$ - deklinacja oraz s - odległość danego punktu na dysku względem punktu $\mathrm{S}_{0}$ w niebieskim układzie równikowym

\begin{tabular}{|c|c|c|c|c|c|c|c|c|c|c|c|}
\hline NP & $\mathbf{p}\left[{ }^{\circ}\right]$ & $\delta\left[^{\circ}\right]$ & $\mathrm{s}[\mathrm{cm}]$ & $\mathbf{N P}$ & $\mathbf{p}\left[{ }^{\circ}\right]$ & $\delta\left[^{\circ}\right]$ & $\mathbf{s}[\mathrm{cm}]$ & NP & $\mathbf{p}\left[{ }^{\circ}\right]$ & $\delta\left[^{\circ}\right]$ & $\mathrm{s}[\mathrm{cm}$ \\
\hline 1 & 16.62 & 73.38 & 14.4 & 16 & 112.99 & -22.99 & 8.2 & 31 & 15.51 & 74.49 & 11.6 \\
\hline 2 & 33.05 & 56.95 & 9.8 & 17 & 125.94 & -35.94 & 14.7 & 32 & 2.96 & 87.04 & 7.7 \\
\hline 3 & 40.81 & 49.19 & 8.5 & 18 & 142.60 & -52.60 & 14.9 & 33 & 10.90 & 79.10 & 11.2 \\
\hline 4 & 32.07 & 57.93 & 14.9 & 19 & 138.63 & -48.63 & 11.2 & $\mathrm{M}$ & 90.00 & 0.00 & 13.8 \\
\hline 5 & 39.55 & 50.45 & 12.2 & 20 & 158.61 & -68.61 & 12.4 & $\mathrm{M}_{1}$ & 60.79 & 29.21 & 14.4 \\
\hline 6 & 42.62 & 47.38 & 10.6 & 21 & 155.78 & -65.78 & 7.5 & $\mathrm{M}_{2}$ & 119.22 & -29.22 & 10.9 \\
\hline 7 & 54.28 & 35.72 & 8.9 & 22 & 173.10 & -83.10 & 11.1 & $\mathrm{M}_{3}$ & 90.00 & 0.00 & 17.0 \\
\hline 8 & 51.21 & 38.80 & 12.0 & 23 & 162.75 & -72.75 & 10.8 & $\mathrm{~S}_{1}$ & 54.73 & 35.27 & 18.5 \\
\hline 9 & 56.20 & 33.80 & 10.6 & 24 & 164.28 & -74.28 & 7.2 & $\mathrm{~S}_{2}$ & 120.14 & -30.14 & 18.4 \\
\hline 10 & 56.30 & 33.70 & 16.5 & 25 & 138.29 & -48.29 & 9.9 & $\mathrm{~S}_{3}$ & 142.26 & -52.26 & 12.3 \\
\hline 11 & 70.75 & 19.25 & 18.4 & 26 & 118.13 & -28.13 & 7.2 & $\mathrm{~S}_{4}$ & 34.63 & 55.37 & 12.7 \\
\hline 12 & 79.93 & 10.07 & 11.9 & 27 & 89.94 & 0.06 & 8.9 & $\mathrm{~B}_{1}$ & 129.74 & -39.74 & 15.5 \\
\hline 13 & 82.68 & 7.32 & 8.2 & 28 & 89.91 & 0.09 & 9.6 & $\mathrm{~B}_{2}$ & 129.76 & -39.76 & 16.3 \\
\hline 14 & 91.39 & -1.39 & 18.3 & 29 & 58.57 & 31.43 & 7.1 & $\mathrm{~B}_{3}$ & 163.84 & -73.84 & 9.0 \\
\hline 15 & 113.11 & -23.11 & 16.7 & 30 & 33.26 & 56.74 & 10.3 & $\mathrm{~B}_{4}$ & 168.37 & -78.37 & 8.6 \\
\hline
\end{tabular}

$1.6 \mathrm{~mm}$ and $0.4 \mathrm{~mm}$, respectively. Based on equation (1), in the case of the zenith line for which $\mathrm{h}=90^{\circ}$, we obtain the value of the latitude $\varphi$ of the observer $(\varphi=\delta)$. Based on the data in Table 5, other directions can also be determined that determine the value of the inclination $\varepsilon$ of the ecliptic to the equator and the tilt and orbit of the Moon to the ecliptic. It turns out that these values are expressed (apart from the angles $\mathrm{M}_{2} \mathrm{~S}_{0} \mathrm{M}, \mathrm{MS}_{0} \mathrm{M}_{1}$ ) by the following angles: $\mathrm{S}_{0} \mathrm{M} 30, \varepsilon_{1}=$ $23.85^{\circ}, \mathrm{S}_{0} \mathrm{M} 24, \varepsilon_{2}=23.68^{\circ}, \mathrm{S}_{0} \mathrm{M}_{3} 32, \varepsilon=23.91^{\circ}, \mathrm{S}_{0} \mathrm{M}_{3} \mathrm{~B}_{3}$, $\varepsilon_{4}=23.83^{\circ}$. Thus, the mean value of the inclination of the ecliptic to the equator, determined on the basis of the four above-mentioned lines is surprisingly precise at $23.82^{\circ}$. Moreover, the angle $\mathrm{S}_{0} \mathrm{M}_{3} 31$ is $29.13^{\circ}$, which is approximately the sum of $\varepsilon+\mathrm{i}\left(29^{\circ}\right)$.

\section{FINAL REMARKS}

This study complements the previous publications [1], [2], the purpose of which was to establish what the Nebra Disc is and what its use had been. The basis of this study is the digitization of objects marked on the disc. The points of the objects symbolizing the "stars", "Moon", "bows", "barges" and "Sun" have been defined by coordinates in the rectangular and polar systems. Thanks to the coordinates, it was possible to calculate the angular values between the selected directions determined by the points of the objects. This, in turn, made it possible to confront the angular values calculated on the disc with the angular values describing the actual position of the Sun and Moon on the celestial sphere, which the disc makers could observe over 3,000 years ago. Describing the points on the disc using coordinates refined their location. This made it possible to determine the exact course of straight lines passing through more than two points. Astronomical knowledge on the Nebra disc was encoded on two horizontal planes and perpendicular to it - meridian. In the geometric and geodetic aspect, all point objects and geometric figures on the horizontal plane are reference points on the Earth's surface. On the presented disc from Nebra, initially, on the horizontal plane, the range of azimuth changes in 
the directions of sunrise and sunset during the year, referring to a belt with a latitude of approximately $51^{\circ}$ $52^{\circ}$, was recorded [4], [1]. A significant scope of astronomical knowledge has been recorded on the meridian plane in the celestial equatorial system and the related geographic and horizontal system. Several examples show the extent of the sun's upper culmination during the year and the extent of the moon's top culmination in its 18.61-year cycle. The use of symbols of the Sun, Moon, solar barge and point objects, the size, shape and location of which perfectly match the text of the message, is admirable. The ambiguity of the meaning of these symbols complicates the disc decryption process. A collection of small gold circles plotted on the disc is considered to be symbols of stars in astronomical terms. Many publications have been written on this premise. Despite numerous attempts, it was not possible to assign them to specific stars or constellations. It is very likely that the points of objects marked on the disc do not represent celestial bodies, but are reference points with which, in the language of geometry, angular information about the position of the Sun and Moon at their upper culmination is recorded. The accuracy of recording such quantities as the tilt of the ecliptic towards the equator and the tilt of the Moon's orbit towards the ecliptic is very high. The mean error of their determination does not exceed $0.1^{\circ}$. The coordinates of a significant number of points on the surface of the Nebra disc and on its circumference, determined with high precision, may constitute the starting data for further studies. The Nebra Disc is in many respects still a mysterious object and inspiring to conduct further research.

This paper was made at AGH-UST within statutory research 16.16.150.545.

\section{REFERENCES}

[1] Góral W., 2020, The Sky Disc of Nebra Reveals its Secrets, Geoinformatica Polonica, Vol. 19, p. 73-80, DOI 10.446 7/21995923GP.20.007.13072, https://www.ejournals.eu/ GP/2020/Vol-19/

[2] Góral W., 2022, Aspekty astronomiczne i geometryczne Dysku z Nebry, URANIA, nr 1.

[3] Meller H., 2004, Słoneczny Dysk z Nebry, National Geographic (Polska), no. 1 (52), p. 45-55.

[4] Schlosser W., Die Himmelsscheibe von Nebra - ein früher Blick des Menschen ins Universum (https://www.astronomie.de/astronomische-fachgebiete/archaeoastronomie/ himmelsscheibe-von-nebra/ein-frueher-blick-des-menschen-ins-universum/ (dostęp 20.11.2021).

[5] Bauhmann E., Pietsch M., Lepcsik M., Jede I., 2005, Interpreting the Bronze Age Sky Disc of Nebra using 3D GIS (https://www.researchgate.net/publication/237745577 Interpreting the Bronze Age Sky Disc_of Nebra using 3D GIS) (dostęp 20.11.2021).

[6] Herten F., Waldmann G., 2018, Functional principles of early time measurement at Stonehenge and Nebra, Archäologische Informationen 41, p. 275-287, doi.org/10.11588/ ai.2018.0.

[7] Pernicka E., Adam J., Borg G., Brugmann G., 2020, Why the Nebra Sky Disc Dates to the Early Bronze Age. An Overview of the Interdisciplinary Results, Archaeologia Austriaca 104, p. 89-122, DOI:10.1553/archaeologia104 s89.

[8] https://www.bibliotecapleyades.net/imagenes arqueo/sky di1.jpg (dostęp 20.11.2021).

[9] https://www.bentley.com/pl/products/brands/microstation (dostęp 20.11.2021).

[10] Dathe H., Kruger H., 2018, Morphometric findings on the Nebra Sky Disc, The Journal of Archeology, Consciousness and Culture, Vol. 11, doi.org/10.1080/175169 6X.2018.1433358.

[11] Draper N. R., Smith H., 1998, Applied Regression Analysis, Wiley.

[12] Green R.M., 1985, Spherical Astronomy, Cambridge University Press. 